\title{
American Advocacy to Education System Development - The Case of Albania
}

\author{
${ }^{1}$ Nikollaq Pano, ${ }^{2}$ Ira Gjika \\ 1,2 Mediterranean University of Albania, Tirana, Albania
}

\begin{abstract}
Human capital development highly affects any country's advancement, regardless of its geographical location. The key role of education in development processes stays at the focus of studies for encouraging further progress. The education's progress has significantly influenced the historical course of Albania during the last 120 years. The establishment and strengthening of secondary and higher education in Albania are among the areas in which U.S. support has been prominent, impacting the country's development. Tracing the Albanian secondary education system at the beginning of the last century leads to the American contribution in vocational orientation. American expertise and consultancy enabled radical changes to economics and business higher education after the 1990s. New study programs and improved curricula were the prerequisite to adapt higher education to the needs of an economy in transition and a changing labor market.
\end{abstract}

Education systems in any country face the challenge to provide qualified and trained staff, capable managers, and executives to successfully expand their companies and economic activity in general. This venture was harder for Albania and other ex-socialist countries of Eastern Europe during the last years of the 20th century, because of a different education system and mindset inherited from their past. The restructuring of Albanian business higher education was facilitated as it relied on the American long-standing pragmatic tradition and institutional contribution.

The paper addresses the history of the higher education changes observed from an individual and institutional viewpoint. The study aims to point out the achievements of the education system in Albania through the support and the impact of the American school. This would assist in a better understanding of Albanian education policies and contemporary processes in a global market.

Keywords: Economic Development, Vocational Education, Business Study Program, Teaching Method.

\section{Introduction}

Investment in education and culture is one of the resources that America has made available to countries in the Western Balkan area to support their development over the past century and ongoing. Its presence in the region is gradually increased in parallel with the support provided. The first Americans who came to Europe during and after the First World War did appear in Albania through missions of medical, technical, educational assistance, etc. Diplomats, school founders, entrepreneurs, expedition scientists, underground explorers, representatives of charitable and religious institutions who came to Albania in the early 1900s were among the first American contributors to build bridges between Albania and the U.S. (Golemi and Golemi, 2012). The relations between Albania and United States officially began in the second decade of the twentieth century, 
when U.S. President Wilson offered the necessary support to the new Albanian state for its recognition (US Embassy in Albania). Diplomatic relations between the two countries were established in July 1922. They were interrupted during World War II and were re-established in March 1991 (www.MEPJ).

It is the time of orientation toward the West for Albania and other Eastern European countries that newly emerged from the socialist camp after the fall of the Berlin Wall in November 1989. According to Gawlicz and Starnawski, the political and economic changes of that time prompted the transformation of the education system of the ex-socialist countries. These countries with similar historical patterns of communism or party-state socialism were making efforts to transit out to some form of democratic government and capitalist economy (Gawlicz and Starnawski, 2018). In this stage, education was a promoter of social transformation as well. The complex role of education in the development of any country under the influence of external factors has prompted this observation in the Albanian environment.

\section{Purpose and Methodology}

The purpose of this paper is to explore the role of American individuals and institutions in supporting the development of Albanian education in a historical context. The key question is how Albanian education has benefited from American experience and contribution in quantitative and qualitative terms over a century. The paper addresses this contribution in two time periods, respectively 1-the beginning of the twentieth century and 2-the last decade of it, which coincide with important stages in the development of our education system.

In methodological terms, the desk study is based on a search of domestic and foreign literature about this topic, both of which are relatively limited. The paper combines the presentation of historical facts with the analysis of factors and elements that have determined the path of advancement of Albanian education, initially secondary and then higher education, under the influence of and with American support. The analysis done by the authors takes the greatest part of the paper and it is closely related to the facts and events presented. This is the reason the literature review could not be presented separately, and it is merged with the findings.

The survey goes beyond the simple presentation of occurrences and dates; it highlights the features that the Albanian education system benefited from contacts with the American experience as a valuable contribution to its further development. In particular, it examines how the transformations of the late 20th century have affected the educational policies and practices in our country.

Undoubtedly, the transformation of the educational system has benefited over the years from the contribution and experience of other Western European countries. Several international organizations, including the World Bank, UNESCO, OECD, have played an important role in the development of education in Albania, especially in the last two decades. However, the reflection of these contributions goes beyond the objectives and possibilities of this work. The complexity of the education system's issues and the timing of events have made it difficult to include them in this survey. It is one of the study's limitations, which can be supplemented by other works or other authors.

\section{Data Analysis and Findings}

\subsection{Theoretical and Practical Education to Promote the Development of a Small Country at the Beginning of the 20th Century}

Many factors of economic and non-economic nature influence the multifaceted development of a country. The mixture of the internal development factors of a country and the geopolitical processes has generally determined the path of progress for small countries like Albania. 


\section{Nikollaq Pano, Ira Gjika \\ American Advocacy to Education System Development - The Case of Albania}

According to Bakker et al (2015), the U.S. did surpass England and other European countries in terms of economic growth by the end of the nineteenth century and took the place of leader in world economic development. The American influence in world economic and political systems did gradually increase, including the Balkan region. Despite the geographical distance between the two countries, a retrospective view of the history of United States-Albanian relations reveals interesting reports, especially in education.

\subsubsection{The Beginning of American Commitment to the Education of Albanians}

The first acquaintance of the Americans with the Albanians is noted during the establishment of the American Evangelical Missions in the territory of the Ottoman Empire, after the development of the Tanzimat Reforms (Asllani, 2011). The descriptions of that time, later documented by scholars, mention the first contacts of American missionaries with the Albanian renaissance and their children. From these contacts, the American missionaries appreciated the great desire and thirst of the Albanians for education, knowledge, and culture and they enabled the first contributions for the education of the Albanian youth. American scholarships provided to many young Albanians in the late 19th century permitted them to study in American colleges and institutes in Princeton, Boston, and Philadelphia, as well as in some schools operating in other countries, geographically closer, such as Bulgaria and Turkey.

The first contribution in Albania was the opening in 1908 of the American Girls' School by the missionary couple Phineas and Violette Kennedy (Jacques, 1993). Despite the great difficulties, their work continued until April 1912, when Korça was occupied by the Greeks and all schools teaching the Albanian language were closed. Later on, the school was reopened, and the missionaries continued their work until 1933 when all private schools in Albania were closed. Dr. Charles Telford Erickson was another American, who began his pedagogical work in Elbasan in those years, but his school was closed by the Turkish authorities ruling in Albania in 1910 (Asllani, 2011).

The efforts of individual Americans in the first decade of the 20th century were followed by more institutionalized and organized activities after the end of World War I. A team of 60 people from the American Youth Red Cross (AYRC) came to Albania in February 1919. This team opened hospitals, anti-TBC and against malaria dispensary in Tirana, Shkodra, Elbasan, Durres, and elsewhere, educated Albanian mothers with hygienic norms, collected orphaned children from the street and placed them in special centers, which later turned into state shelters. But above all, the AYRC organization had a unique role in Albanian education.

The AYRC headquarters in Washington sent its representative O. M. Salisbury to Albania to observe the urgent needs of the country in September 1919. During the visit, Salisbury noted the complete lack of schools and the great desire of Albanians for education. He immediately recommended providing scholarships for young people who wanted to study in American colleges in Istanbul, as well as suggested the opening of agricultural and vocational high schools in Albania.

Consequently, with the financial assistance of the AYRC and under the auspices of the then Ministry of Education, the first vocational school, the American Technical School, opened its doors in July 1921 by the American representative John C. Crawley (Asllani, 2011) (www.IHF). This event marked a starting point for the development of vocational education in Albania and, at the same time, paved the way for the creation and adaptation of the secondary education system in a country where the majority of the population was illiterate.

\subsubsection{Principles of Learning from the American Tradition at the Beginning of the Last Century}

The passage of many foreign powers in the Albanian territories has left traces in the establishment of educational institutions with different influences. There was a variety of languages in which they operated, a diversity of didactic models, as well as different orientations towards learning and acting. 
American-based schools established in Albania differed in several characteristics, which brought influence on Albanian education in general, mainly in the period between the two world wars.

1. The first characteristic of the influence of American culture in the Albanian education system was the connection of education with the level of economic development of the market.

The history of the economic system development in Albania in the years 1925-1935 shows the introduction of foreign investment, especially from neighboring countries, but also the creation of a series of small and medium-sized businesses from local investors. The General Electric company entered the Albanian market for the first time with a hydropower plant in Vithkuq, SITA \& SESA in Tirana, the Cigarette Tobacco Factory in Durrës, the Cement Factory in Shkodra, etc. Before the great crisis of '29 -'33, there was a dynamic business growth in Albania, mainly in the country's infrastructure, handicrafts and agriculture. The drafting of the commercial code and a western legal basis marked the creation of the management system for joint-stock companies operating with Albanian, mixed, or foreign capitals. Only two joint-stock companies were operating in the Albanian market during 1921-1924, with a capital of 300 thousand gold francs, while 14 other joint-stock companies did establish in the period 1925-1928, with a capital of over 7,620 thousand francs (Banja, 2012).

Until these years, the industry was almost non-existent, and the country's economy relied on the agricultural sector. Vocationally qualified staff was coming from foreign schools because there was no vocational education in the country. Furthermore, the education system should necessarily serve to the development and modernization of agriculture and livestock, as well as to the start of the industry. It was precisely this orientation of schooling toward the market needs that came as an American contribution, with the American Technical School in 1921. In the newly opened school, the main branch was agronomy and, after that, the technical branch (mechanics, electricity, construction) and the teaching one. From 1922 until its nationalization in the year 1933, this school was run with talent and professionalism by Harry Fultz, whose name it took later and still holds (www.IHF).

The changes in the market structure required new knowledge related to industrial development. There was a demand for specialists, especially with the knowledge of electricity, mechanics, hydraulics, etc. These needs stimulated the changes in school curricula of the time and the extension of different profiles in existing schools in Albania. The Technical School offered a wide range of professional programs and provided students with distinct theoretical and practical knowledge. Students were carrying out numerous sports, cultural activities and publishing their newspaper. The quality of the programs enabled school graduates to be admitted to the most prestigious universities in U.S. and Europe. (www.IHF)

The Albanian-American Institute, known in Albania as the American Agricultural School of Kavaja, is another institution that had highly influenced the development of market-oriented vocational education as well as the development of Albanian agriculture. It started its activity in 1926, founded and run by American specialists (Dr. Telford Erikson) and its first graduates were ten students in 1930 (Asllani, 2011). The school leaders had the intention to fill a gap for agricultural mechanics, accountants, and craftsmen in the labor market, by offering trained staff in this school.

2. Another attribute of American influence in the Albanian education system was the set-up of the close linkage between theoretical education and professional practice.

The quantitative changes that the education market in Albania was undergoing at this stage were followed by important qualitative achievements based on teaching and learning methodologies. The American learning system is based on the paradigm of necessary and usable knowledge in every context. Unlike secondary education organized in other cities such as Shkodra and Korca, mainly under Austrian, Italian, and Greek influence (to give the culture and language of the country that founded it), teaching in the American style was practical, tangible, and concrete. It was providing all 


\section{Nikollaq Pano, Ira Gjika \\ American Advocacy to Education System Development - The Case of Albania}

the theoretical elements required for the practical implementation of processes, procedures, and for problem-solving. In general, there were two main directions outlined in the Albanian education system during the period from 1920 to 1944: the one of theoretical learning based on the European school and that of practical learning, based on American tradition. While the first aimed to teach students who could further study abroad and create a generation of young Albanian intellectuals, the second one was providing graduates who could work and run all kinds of businesses operating in Albania. Certainly, learning from the 'American style' did not prevent further studies; however, it was in essence preparing students to enter the labor market as quickly as possible and to adapt to the respective professions more easily.

The objective of the Agricultural School of Kavaja was to form the future administrators and specialists of agriculture. There were 177 agronomists who graduated along 14 years of school's functioning, of which 65 persons were engaged in agricultural work and were employed as agricultural agents in the local administration, 48 persons took over the administration of their land and property, 19 became teachers and 21 continued their studies at European and US universities. American schools in general, especially that of Kavaja with American professionals and talented teachers, have significantly contributed to creating a body of educated farmers, which later became the intellectual elite of Albanian agriculture.

3. The third characteristic of the American influence in the Albanian education system was the teaching and introduction of new technologies in the market.

Learning from the most advanced models was the moto to enable development. This approach was applied in agricultural schools with the queue of sowing crops not randomly but according to the needs of the land, in livestock with the introduction of new breeds and the implementation of food regimes, in the processing of livestock products according to best food technologies of that period, etc. The agricultural school of Kavaja had two tractors, some planting and trimming machines and other agricultural equipment in 1929 (Asllani, 2011).

Much more prominent was this process in the electrical, mechanical field and professions such as plumbing and machine mechanics. In the technical school of Tirana, the students used tools that had not yet entered the Albanian market and materials that were very little known. The power plant of the school was giving light to the city, and its printing press provided publications in town (www. IHF). The students from this school were the first promoters of technology advancement (of the time). Thus began a technology transfer process that, although in a small market, became an important driver of development.

\subsection{The Second Stage of American Influence and Support for Albania and the Countries of the Balkan Region. Developing a Market Economy Through Education.}

The U.S. has organized campaigns of foreign aid to other countries mainly led by strategic and ideological perspectives. According to Prud'homme (2007), the U.S. set up several aid agencies to rebuild Europe after the Second World War through the Marshall Reconstruction Plan. It is historically known that it could not work for Albania at the time due to the regime in power, which closed the road to American support and directed the country toward the East.

The opportunity appeared again after the fall of the Berlin Wall in 1989. The U.S. government undertook development assistance programs for the countries of the Central and Eastern European (CEE) region, known as the Newly Independent States (NIS) during the early 1990s. The U.S. Agency for International Development organized the Management Training and Economic Education Projects (USAID MTEEP). These projects provided funds for partnerships between 10 American universities and 9 universities in Central and Eastern European (CEE) countries: Albania, Bulgaria, Czech Republic, Hungary, Latvia, Lithuania, Poland, Romania, and Slovakia (McIntyre, Alon, 2005). At the time became clear that "one of the biggest challenges for the former Eastern bloc countries is to develop an educational system that builds on their past, yet is oriented towards the present and future" (De Simone, 1996). 


\section{Nikollaq Pano, Ira Gjika}

American Advocacy to Education System Development - The Case of Albania

From a theoretical point of view, according to field studies (McIntyre, Alon, 2005), a unique system of business education, tailored to the needs of the country and based on best practices and lessons, would make it possible to prepare talented, qualified, and highly motivated professionals. A generation of local employees trained to manage activities in a competitive environment is a prerequisite for attracting foreign direct investment. In turn, FDIs create jobs, reduce brain drain, create opportunities to expand into international markets as part of the supply chain, and ensure continued profits from increased productivity (Bakker et al., 2015). Due to the chain effect, all the above-expected benefits can generate vital export sectors for growth and diversification.

In front of these needs, American business and education specialists in the early 1990s described the level of expertise in CEE countries as follows: "These countries generally have an educated and intelligent workforce. However, there is a lack of practical knowledge and management skills needed to run private enterprises in a market-driven economy" (Lee, Luthans, Hodgetts, 1992). According to Lee and his colleagues "companies in Central and Eastern Europe need a lot of help from the West". Moreover, the increasing importance of quality goods and services requires total quality management (TQM) to be among the modern management methods and approaches that firms in CEE countries should apply.

These findings and suggestions formed the basis that prompted the U.S. and other Western countries to provide technical assistance grants for economic education in Albania after 1990. With USAID support in 1992, a group of professors and entrepreneurs, mostly from the University of Nebraska, began a project in Albania to train government officials, teachers, and business people in the western style of management and market economy. The motto was: "The future of Albanians depends on the effective use of the rich human capital that this country has, especially young business students and entrepreneurs" (Lee, 2001).

The experience of the last decades for emerging countries and those in transition shows that they have created their leading elites through different ways (Alon et al., 2013). Models include sending future managers to business schools in developed countries or "importing" ready-made Westernstyle business programs to meet the demand for training locally. Given the role of human capital and education in the advancement of economies, the reorganization of the education system is considered the reform with the greatest impact on a country in the process of development or transition.

The economics study programs in the United States are generally offered by business schools, or sometimes by the social sciences institutions. In Eastern European countries, business and/or management schools were most often part of an economics school (not the other way around) until the '90-s. Due to fundamental political and economic changes after the year 1989, some of them were reorganized and renamed as schools of economics and management or increasingly as schools of business, following the model of the American schools. Alon et al believe this evolution may have been because the pre-reform education system was focused on political economy and (international) trade. Consequently, they consider a logical step the adding of business programs to the existing economic schools (Alon et al., 2013).

\section{Discussion}

The American contribution to the organization of business and management university education becomes evident by factual investments in the structure and infrastructure of higher education in Albania. Some of the key elements of this contribution are highlighted below, keeping in mind the social background and the time when they did happen. Even though currently, about 3 decades later, the advancement of the Albanian business school has made it comparable to higher education in other countries of the world, its current value would be unclear without the foundations laid in the early '90s. No matter if they seem small and insignificant in today's metrics. 
1. The strong connection between university education and the labor market is the primary feature to lead the reorganization or reform in business studies in Albania.

The opinion of American business specialists in the early '90s was that "In general, the Albanian school system is well developed and there is a tradition of a sound education. However, Albanian higher education institutions are unprepared to provide modern business education for future executives" (Lee and Trimi, 2004). Consequently, the need for a sound education in the business field is essential for the success of a small country with limited foreign resources and investment. Albania could develop a market-based economy through the education of future businessmen (https://www.unl.edu/).

According to Lee, 2004, the project that started in March 1992 had two main challenges. The first challenge was to offer a general education program for employees in state institutions, staff of the Faculty of Economics, and several entrepreneurs. There were organized massive and comprehensive training programs for providing knowledge on the principles of market economy, management, entrepreneurship, and marketing, which were lacking in that period. As reported by USAID (1998), the first training program included about 450 people for a five-day program in Tirana. From then until the early 2000s, over 6,000 people were trained through basic and/or advanced, focused, and on-site programs (USAID, 1998). Most of the training programs were in the main cities - Tirana, Korca, Shkodra, and Vlora.

The second challenge was the consultancy and assistance for the complete restructuring of the business school curriculum in Albania. At that time the Faculty of Economy at the University of Tirana was the only school offering economics and business programs. The objective was to strengthen the Albanian academic infrastructure in economics and business study programs.

There were radical changes made to the curricula, going from titles to the content of courses, from the first sets of lectures to the textbooks afterward. Those transformations are in the memory of all the staff engaged in economics and business higher education of that period (including the authors of this paper). The American curriculum model gradually and almost entirely determined the course structure of the study programs in the early years. This influence culminated with the organization and opening at the University of Tirana of the first and the only Master program in Business Administration in Albania in 1996. Lee (2004) remembers that the first class consisted of 30 students selected among 80 applicants. It is recorded as the first MBA program across CEE set up in line with the international education standards and licensed by the government (Lee and Trimi, 2004).

This schooling model is based on the principle of continuous (life-long) learning. It was implemented almost simultaneously in several CEE countries. The first graduates of earlier programs entered the job market in late 1997, equipped with new skills and knowledge for managing and running companies and institutions. Lee and Trimi (2004) mention seven Master of Business Administration (MBA) programs operating in five countries (Albania, Hungary, Latvia, Poland, and the Slovak Republic), with around 1,000 students enrolled. They report that about 200 students had received their MBA degrees, and another 200 were expected to complete their studies by the spring of 1998 (Lee and Trimi, 2004). Although few of the programs had achieved official recognition, Hull (1999) points out that MBA graduates were succeeding in the job market, in large foreign firms, and in a number of start-ups that were coming out of the informal sector.

2. The curriculum content and its realization process are both determinants of the expected achievements of the business education system.

This sense of the reformed education system was conveyed through the American experience in the four-year system and especially in the master program at the Faculty of Economy, where teaching was initially carried out by American staff. Traditional lectures and routine learning methods were typical in many transition countries because of the previous schooling tradition "chalk and talk". The American professor De Simone comments it in 1996 while visiting some of CEE countries "Although 
we have had the freedom to develop new methodologies to foster and nurture analytical and critical thinking, as well as metacognitive and interpersonal skills, such has not been the case in Eastern Europe". Along with the new curriculum, a change in teaching and learning methods was encouraged. They focus on the use of interactive models, practice group work, encourage critical thinking, and the use of technology in school. The USAID project and the contribution of the consortium of American universities did enable the use of customized training software, video tutorials, computer presentations. For students to master management skills, academic staff must integrate teaching with business practice. On the other hand, it is necessary to change the method of knowledge assessment, going from knowledge-based assessment to competency-based assessment.

One of the greatest influences of the American teaching methodology at the university level used in the CEE schools, including Albania, is pushing the education to be based on skills, known as Soft Skills. This concept summarizes the totality of knowledge and competencies that create capacities and skills for certain processes or tasks. It goes through a particular form of learning that "connects persons (students) with business organizations processes in the moments of their professional growth, despite the fact that they are in constant transformation" (WEF, 2016). Nowadays the digitalization of the economy, new methods of production, and frequent changes of occupations are further encouraging this learning form.

The market demands and imposes constant changes to all businesses, the Albanian ones as well. They set new goals with new production visions. It, in turn, requires specialized human resources, which necessarily leads to a reassessment of curricula to provide students with usable knowledge and skills. The American concept of learning aims to create a climate called "Open Innovation", an environment where students "in a free but also mandatory" way should combine the theoretical concepts with real business problems and contribute to their solution. Thus, Albanian universities are using these methods of learning from the benchmark universities.

3. Entrepreneurial education in Albanian university programs encouraged by the American experience.

Increasing the entrepreneurial spirit in all levels of university education is a direct impact of American 'doing business' education. The establishment of structures, currently known as Business Incubators, Business Accelerators, measuring the probability of new business ideas, and other ways to stimulate new businesses remains a very popular practice in the U.S. Economic policies based on innovation and new technologies are drivers for increasing youth employment and sustainable development, but also self-employment, small business development and the sale of labor product and not working time. The experience of American universities as a source of expertise and partnership to businesses did influence the designation of one of the objectives the USAID project for education in Albania had. The use of intellectual resources from higher education to support the needs of local business organizations and other institutions in the country was realized via the establishment of Business Assistance Centers. Reports from USAID (1998) confirm that since 1996 the project has established three Business Assistance Centers (BAC) at the Universities of Korça, Shkodra, Vlora, and the Technology Management Center (TMC) at the Polytechnic University of Tirana (UPT). The centers have provided a number of training and education programs for local business communities, as well as counseling services for small business owners. In addition to these training programs, the centers were also engaged in market research, feasibility studies for new ventures, and analysis of labor force and skills required. Student groups called SIFE (Students in Free Enterprise) were formed at four national universities in order to encourage entrepreneurship among students (Lee and Trimi, 2004). The table below provides a summary of figures for the American contribution to the business higher education in Albania. 
Table 1: Partial data on American contribution to business higher education through projects realized in Albania.

\begin{tabular}{|l|l|l|}
\hline Time & Activity & Outcome \\
\hline $1992-1993$ & 5 -days trainings on market economy & $\begin{array}{l}\text { 450 participants from universities, } \\
\text { ministries, business organizations }\end{array}$ \\
\hline $1992-1994$ & $\begin{array}{l}\text { Business program curricula, the } \\
\text { composition of course lectures in the } \\
\text { Albanian language }\end{array}$ & $\begin{array}{l}4 \text { universities - Tiranë, Shkodër, Vlorë, } \\
\text { Korcë. }\end{array}$ \\
\hline March 1996 & $\begin{array}{l}\text { Opening of the first Master of Business } \\
\text { Administration (MBA) program in } \\
\text { Albania }\end{array}$ & $\begin{array}{l}80 \text { applicants, 30 graduated students } \\
\text { in the first cohort }\end{array}$ \\
\hline 1996 & $\begin{array}{l}\text { Provision of literature and technology. } \\
\text { Establishment of Business } \\
\text { Assistance Centers. }\end{array}$ & $\begin{array}{l}180,000 \text { textbooks, 80 computers, and } \\
\text { auxiliary materials donated - basis for } \\
\text { "Joseph Limprecht" Library at the } \\
\text { Faculty of Economy, University of } \\
\text { Tirana. }\end{array}$ \\
\hline $\begin{array}{l}\text { February } \\
2002\end{array}$ & $\begin{array}{l}\text { Opening of the first Master of Public } \\
\text { Administration (MPA) in Albania. }\end{array}$ & 35 students in the first cohort \\
\hline
\end{tabular}

Source: processed by the authors, according to data from Lee, Trimi, 2004, USAID -Albania, 1998.

\section{Conclusions}

History has shown that the development and future of countries have been affected by a multitude of interactive forces. Geopolitics, economic growth or downturns, technological breakthrough, and social changes are some of the most influential drivers every country must consider for its further advancement. In all cases, human resources and the education of generations are essential. The capability of the education system to provide the required and useful knowledge, skills, and culture to students is reflected in all economic and other activities the workforce is engaged in for decades. The American model of vocational education and the direct American contribution enabled the establishment of vocational secondary education in Albania in the 1920s. It was a contribution that did accompany and support the economic development of the country by offering a functional and advanced curriculum, and pedagogical approaches for the time.

Similarly, American universities became the basis and model for the development of higher business education in the 1990s. In addition to the financial contribution, their major role was in orienting to face challenges such as:

- what curriculum would work best in the Albanian environment,

- how the Albanian school would meet the needs of the market economy for business professionals,

- what role could / should the business school play in creating an entrepreneurial culture or promoting economic reforms,

- how technology transfer could affect management education.

The study has addressed these issues in a historical context. It has highlighted facts and has done some analysis about topics only slightly observed before. This remains a research area where there is much to explore yet. Our work is an unpretentious endeavor to contribute to a well-designed and contemporary education system in Albania in a period of all-around globalization.

\section{Acknowledgements}

The authors are grateful to the colleagues from business higher education institutions who have been active players in the abovementioned transformation during the ' 90 s and have shared their opinions about the process. Special thanks to the Editors of the Journal for the valuable comments on the previous version of the paper which has improved its quality and content to the present state. 


\section{References}

- Akademia e Shkencave e Shqipërisë, Fjalor enciklopedik shqiptar, (Vëllimi I), Tiranë, 2008, (Academy of Sciences of Albania, Encyclopedic Dictionary, vol.1), http://www.akad.gov.al

- Alon, I., Jones, V., McIntyre, J. R., - Innovation in Business Education in Emerging markets, United Kingdom, 2013. CrossRef

- Asllani, U., - Misioni i amerikanëve në Shqipëri dhe ndihma për arsimin, Tirane, 2011. (The mission of Americans in Albania and support to education).

- Bakker, G.; Crafts, N.; Woltjer, P. - A Vision of the Growth Process in a Technologically Progressive Economy: The United States, 1899-1941. March 2015.

- Banja, H. - "Ekonomia e Shqiperise ne rrjedhat e historise se shekullit te XX", 2016. (Economy of Albania in the course of the history of XX-th century)

- De Simone, D.M., Educational Challenges facing Eastern Europe, 1996, (retrieved from http://www. socialstudies.org/sites/default/files/publications/se/6002/600207.html)

- Gawlicz, K., Starnawski M. Educational policies in Central and Eastern Europe: legacies

- of state socialism, modernization aspirations and challenges of semi-peripheral contexts Policy Futures in Education, 2018, Vol. 16(4) DOI: 10.1177/1478210318777415 CrossRef

- Golemi, Z., Golemi, A. - Marrëdhëniet me amerikanët në fokus historik njëshekullor, Illyria Press, 2012. (Relations with Americans in a centennial historical focus)

- Hull, G.S., Small businesses trickling up in Central and Eastern Europe, New York, 1999.

- Jacques E.E, Rev. and Mrs. Phineas B. Kenedy: A Tribute, 1993, (retrieved from https://reformation.edu/albania/pages/phineas-kennedy.htm)

- Konrad-Adenauer-Stiftung e. V. (KAS) - The influence of external actors in the Western Balkans, 2018.

- Lee S., Luthans F., Hodgetts R. - Total Quality Management: Implications for Central and Eastern Europe, Organizational Dynamics 1992, Spring, 42-55. CrossRef

- Lee, S.; Trimi, S. - Developing Business Education Infrastructure in Eastern Europe: Albanian Experience, International Journal of Public Administration, Vol. 27, Nos. 11 \& 12, pp. 869881, 2004. CrossRef

- McIntyre, J. R., and Alon, I. - Business and management education in transitioning and developing countries: a handbook, 2005 New York.

- Prud'homme, D. - Assessing the Millennium Challenge Corporation as a Model for Foreign Assistance Reform, June 2007, working paper, United States Agency for International Development's Development Experience System (DEXS) http://dec.usaid.gov.

- USAID Albania Strategic plan FY 1998-2002, 1998. https://dec.usaid.gov/dec/search/FusionSearchResults.aspx?q=USAID.\%20Mission\%20to $\% 20$ Albania

- World Economic Forum (WEF) - The future of Jobs Report, 2016;

- https://al.usembassy.gov/our-relationship/policy-history/io/

- $\quad$ http://harryfultz.edu.al/historiku/

- http://www.kavajaonline.com/forumi/topic/3310-instituti-bujqesor-shqiptaro-amerikan-ikavajes/

- https://www.unl.edu/

- http://punetejashtme.gov.al/marredheniet-dypaleshe/marredheniet-me-shtetet-ebashkuara-te-amerikes/ (www.MEPJ). 